\title{
Short Communication: Identification of the exon 1 myostatin gene polymorphism and its association with slaughtered weight in Indonesian Kampung and Broiler Chicken
}

\author{
LINDA SUHARTATI ${ }^{1, \bullet}$, ISYANA KHAERUNNISA ${ }^{2}$, ASEP GUNAWAN ${ }^{3}$, RUKMIASIH $^{3}$, SRI DARWATI ${ }^{3}$, \\ CECE SUMANTRI ${ }^{3}$, RIZQAN $^{1}$ \\ ${ }^{1}$ Department of Animal Science, Faculty of Animal Science, Universitas Andalas. Jl. Raya Unand, Padang 25163, West Sumatra, Indonesia. \\ Tel.: +62-751-71464, Fax.: +62-751-71464, `email: lindasuhartati@ansci.unand.ac.id \\ ${ }^{2}$ Departement of Animal Science, Faculty of Agriculture, Universitas Bandung Raya. Jl. Cikutra No. 171, Neglasari, Bandung 40124, West Java, Indonesia \\ ${ }^{3}$ Department of Animal Production and Technology, Faculty of Animal Science, Iinstitut Pertanian Bogor. Jl. Agatis, Kampus IPB Darmaga, Bogor \\ 18860, West Java, Indonesia
}

Manuscript received: 10 June 2020. Revision accepted: 31 July 2020

\begin{abstract}
Suhartati L, Khaerunnisa L, Gunawan A, Rukmiasih, Darwati S, Sumantri C, Rizqan. 2020. Short Communication: Identification of the exon 1 myostatin gene polymorphism and its association with slaughtered weight in Indonesian Kampung and Broiler Chicken. Biodiversitas 21: 3893-3897. Myostatin is widely known as a negative regulator of skeletal muscle development by controlling hypertrophy and hyperplasia. Silent mutation in exon 1 (c.234G>A) was then thought to be associated with chicken growth performances. This study was designed to analyze polymorphisms of c.234G>A mutation of the myostatin gene and its effect on slaughtered weight in Indonesian Kampung and meat-type chicken. The SatI restriction enzyme was used for genotype determination through the PCR-RFLP technique. The effect of genotype on the slaughtered weight was analyzed using the General Linear Model (GLM) procedure. Genotyping was performed on 138 chicken from Kampung ( $n=67)$ and meat type (cobb Broiler) $(n=71)$ chicken. The amplification product contained $226 \mathrm{bp}$ nucleotides. This myostatin gene was polymorphic in both chicken population, produced 2 alleles ( $\mathrm{G}$ and $\mathrm{A}$ ), and 3 genotypes (GG, GA, and AA). The A allele had a higher frequency than the $\mathrm{G}$ allele in all populations. In this study, genotype of AA and GA had higher live weight, carcass weight, breast weight, thigh weight, drumsticks weight, wings weight, breast muscle weight, thighs muscle weight, drumsticks muscle weight than GG genotype of 12 weeks-old Kampung chicken. The results suggested that the c.234G $>$ A mutation in exon 1 could be potentially recommended as a genetic marker for chicken slaughtered weight traits.
\end{abstract}

Keywords: Kampung chicken, meat-type chicken, myostatin gene, PCR-RFLP, slaughtered weight

\section{INTRODUCTION}

The demand for animal protein products is increasing in line with the increasing of Indonesian population. The source of animal protein in Indonesia is generally dominated by Broiler meat. Broiler is well known as a very effective meat producer. Broiler strain Cobb is one of the Broiler strains in Indonesia with special characteristics, such as low feed consumption rate, genetic development directed at the formation of breast meat, and adaptive to the tropical environment (heat stress). The economic properties of Broiler chickens are growth performance, carcass quality, meat quality, disease resistance, and also health benefit aspect. Carcass quality is one of the parameters that are now starting to be concerned as one of consumer's favorable meat characteristics.

The efforts to improve the local chicken productivity can be done through selection in molecular level. Biotechnological advances of molecular genetics through genetic markers based on functional genes could be an effective, accurate, and efficient alternative for selection of growth and meat production. One of the important genes that control the nature of growth and meat production is Myostatin (MSTN) gene. Beyer et al. (2013) added that Myostatin (MSTN), also known as growth and differentiation factor 8 (GDF8), is the major regulator of skeletal muscle development. According to Stinckens et al. (2010), Lee (2010) and Breitbart et al. (2011) Myostatin (MSTN) is a member of the transforming growth factor (TGF)- $\beta$ superfamily and a negative regulator of skeletal muscle growth. MSTN is predominantly expressed in skeletal muscle (Naji et al. 2014; Boman et al. 2010). The chicken MSTN gene is located in chromosome 7 which consists of 3 exons and 2 introns. More than 20 SNP in chicken MSTN has been reported along 5'UTR to 3'UTR (Genxi et al. 2014). Previously, our study in exon 2 MSTN gene reported strong association between genotypes and carcass characteristics of F2 Kampung x Broiler chicken cross (Khaerunnisa et al. 2016). Zhang et al. (2012) found that the point mutation c. $234 \mathrm{G}>\mathrm{A}$ in exon 1 in Bian chickens was associated with growth properties. In Indonesia Kampung chickens and Broilers chicken, there is no data on the effect of MSTN gene on exon 1 with growth and carcass characteristics. This study was conducted to 
identify the Exon 1 MSTN genetic polymorphism and to analyze the association of genotypes on carcass characteristics of Indonesian Kampung compared to meat type Broiler chicken. This study can be useful as a Marker Assisted Selection (MAS) candidate and could be applied to strengthen national food security from meat.

\section{MATERIALS AND METHODS}

\section{Chicken populations and data collection}

The total sample used for the identification of MSTN gene polymorphism was 138 individuals consisting of 12week old Kampung chicken $(n=67)$ and 12- week-old Broiler chicken (71 chickens). All animals were bred in the Animal Breeding and Genetics Division, Department of Animal Production and Technology, Faculty of Animal Science, Bogor Agriculture University (IPB), Indonesia. All animals used in the current study were maintained according to the principle of animal welfare. Carcass characteristics of Broiler and Kampung chicken were measured and collected. Characteristics of the carcass included live weight, carcass weight, breast weight, thigh weight, drum sticks weight, wing weight, breast muscle weight, thigh muscle weight, drum sticks muscle weight, and percentage of each carcass part and muscle.

\section{DNA extraction}

The DNA extraction procedure was based on the phenol-chloroform method (Sambrook and Russel 2001). DNA extraction started with $1 \mathrm{~mL}$ blood sample collection from wing vein. Furthermore, $20 \mu \mathrm{L}$ blood was added with $1000 \mu \mathrm{L}$ of Sodium Chloride $(\mathrm{NaCl}) 0.2 \%$ and stand for 5 minutes. Sample then was centrifuged at $8000 \mathrm{rpm}$ for 5 minutes and the supernatant past was removed. The precipitate obtained was added with $10 \mu \mathrm{L}$ proteinase $\mathrm{K}$ (5 mg mL-1), $40 \mu \mathrm{L}$ Sodium dodecyl phosphate (SDS) $10 \%$, $30 \mu \mathrm{L} 1$ x STE, then incubated at $55 \mathrm{oC}$ for $2 \mathrm{~h}$ while gently mixed by using nutating mixer. After incubation, the sample solution was added with $400 \mu \mathrm{L}$ phenol, 400 Chloroform isoamyl alcohol (CIAA), $40 \mu \mathrm{L} 5 \mathrm{NaCl}$ mixed for $1 \mathrm{~h}$ at room temperature. After that, the solution mixture was centrifuged at a rate of $12000 \mathrm{rpm}$ for 5 minutes to form a clear DNA phase. The DNA phase was removed into a new tube and then added $800 \mu \mathrm{L}$ of absolute $\mathrm{EtOH}$, $40 \mu \mathrm{L} \mathrm{NaCl} 5 \mathrm{M}$, and stored into the freezer for 12 hours. The DNA samples were then centrifuged for $5 \mathrm{~min}$ at 12 $000 \mathrm{rpm}$ to separate the absolute EtOH. The supernatant part was removed and allowed to remain open at room temperature until ethanol was completely evaporated. After that, $100 \mu \mathrm{L}$ TE $80 \%$ was then added. The DNA samples can be stored in the freezer for long term use.

\section{Primer designing and PCR amplification}

Primers to amplify the c.234G>A myostatin fragment target in exon 1 were designed using Primer Designing Tool (http://www.ncbi.nlm.nih.gov/tools/primer-blast/) according to Gen Bank (accession number AF346599). The c. $234 \mathrm{G}>\mathrm{A}$ mutation was based on Zhang et al. (2012). The primers used were forward primer 5'-TCA AAT CCT CAG CAA ACT GCG-3' and reverse primer 5'-ACG AAA GCA GCA GGG TTG TT-3'. These primers generated 226 bp DNA fragment. PCR was performed with a total volume of $14.5 \mu \mathrm{L}$ for each reaction containing $50 \mathrm{ng} / \mu \mathrm{L}$ DNA samples, 0.5 pmol primers, and 0.5 unit Go Taq ${ }^{\circledR}$ Green Master Mix (Promega, Madison, USA) and water. This mixture was incubated in a thermocycler machine (Gene Amp PCR System 9700, Applied BioSystems TM, Foster City, USA). The amplification process was run with 35 cycles consisting of denaturation at $95{ }^{\circ} \mathrm{C}$ for $10 \mathrm{sec}$, annealing at $60{ }^{\circ} \mathrm{C}$ for $20 \mathrm{sec}$, and elongation at $72{ }^{\circ} \mathrm{C}$ for $30 \mathrm{sec}$.

\section{Restriction Fragment Length Polymorphism (RFLP) and visualization of DNA fragments}

The SatI (Thermo Fisher Scientific, EU, Lithuania) restriction enzyme was used for genotype determination. The PCR product was incubated at $37^{\circ} \mathrm{C}$ for $2 \mathrm{~h}$. The allele and genotype identification were visualized through electrophoresis analysis in $2 \%$ agarose gel, which was stained with $1.8 \mu \mathrm{L}$ Fluorosafe DNA stain (1st Base, Singapore) above UV Transilluminator (Alpha Imager, Alpha Innotech, Santa Clara, USA).

\section{Data analysis}

Genotype frequency, allele frequency, heterozygosity were used to analyze polymorphism information according to Nei and Kumar (2000) and Hardy-Weinberg Equilibrium, according to Allendroft et al. (2013). Statistical analysis of associations between genotype and carcass characteristics were analyzed using the SAS General Linear Model (GLM) procedure (SAS, 2008). Duncan's multiple range test was used to identify significant differences between means. The genetics effects were analyzed using the following model:

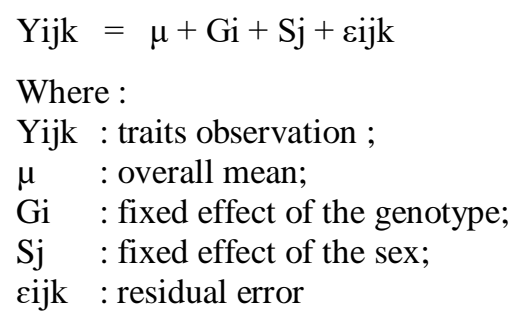

\section{RESULTS AND DISCUSSION}

\section{Amplification of MSTN genes}

The MSTN gene in exon 1 was amplified with a length of $226 \mathrm{bp}$ (Figure 1). The length of PCR products was different from that amplified by Zhang et al. (2012), which is $162 \mathrm{bp}$. It was because the primers difference is used to detect the point mutation. The length of the product is too short of making it difficult to detect the bands after cutting using enzymes. 


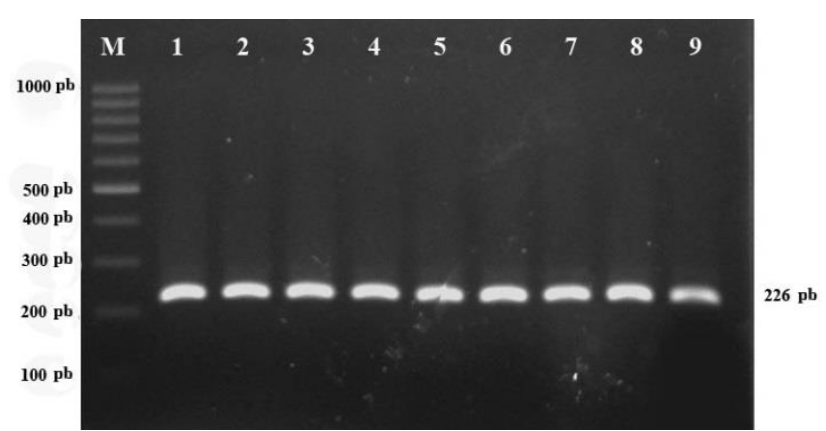

Figure 1. Visualization of myostatin gene amplification $1.5 \%$ agarose gel (M: marker 100 bp; 1-9: samples)

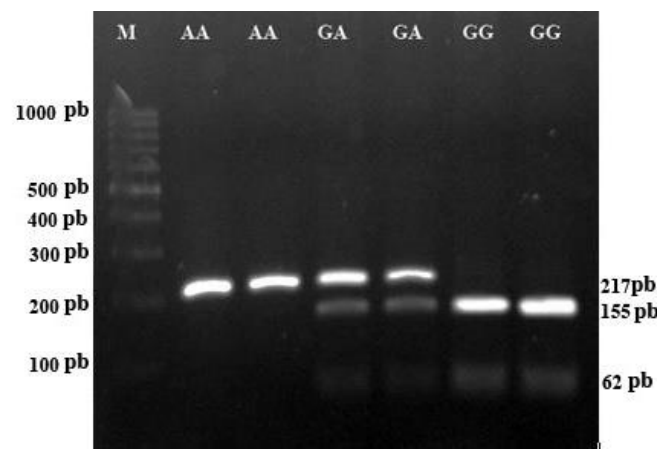

Figure 2. Visualization of myostatin|SatI genotyping in $2 \%$ agarose gel (M: marker, AA, GA, GG: genotype)

SNP in c. $234 \mathrm{G}>\mathrm{A}$ was identified through the GC | NGC cutting site using the SatI enzyme. Genotyping using SatI restriction enzyme successfully identified two alleles (A and $\mathrm{G}$ ). The two alleles derived three genotypes (AA, GA, and GG). The $\mathrm{G}$ allele was indicated by 3 bands $(155,62$, and $9 \mathrm{bp}$ ), and A allele was indicated by 2 bands (217 and 9 bp). The GA genotype was indicated by 4 bands (217, 155, 62, and 9 bp) (Figure. 2). However, the visualization results PCR-RFLP could not show 9 bp because the length of the band was too short.

\section{Polymorphisms, heterozigosity and Hardy-Weinberg equilibrium}

The genotype, allele frequency, heterozygosity, and chisquare of MSTN genes were described in Table 1. The bian, jinghai, youxi, arbor acre chickens used as comparators were obtained from Zhang et al. (2012). All population showed that c. $234 \mathrm{G}>\mathrm{A}$ mutation were polymorphic with two alleles found (A and $G$ ). The frequency of allele A was found to be higher in the Kampung, Broiler chicken, Jinghai, Youxi, and Arbor acre, except Bian chicken. The frequency of the A allele was found to be highest in the Broiler chicken population (0.940). In Bian chicken, the A allele (0.40) was lower than the $\mathrm{G}$ allele (0.60).

The frequency of genotype AA was found to be higher in Kampung, Broiler, Jinghai, and Arbor Acre chicken. The frequency of genotype GA was found to be higher in Youxi chicken and in Bian Chicken of the highest GG genotype frequency. In Broiler and Arbor, acre chicken was not found GG genotype. Polymorphisms can be analyzed by using heterozygosity numbers (Table 1). The observed result indicates that in the population of Kampung and Broiler chicken has a low polymorphism of mutation in c. $234 \mathrm{G}>\mathrm{A}$. The observed heterozygosity (Ho) number in Kampung chicken was higher than He. However, the Ho number in the Broiler chicken population equal to $\mathrm{He}$ number. The $\chi^{2}$ analysis showed that all population of chicken were in equilibrium with the Hardy-Weinberg's equation.

\section{Association of MSTN polymorphisms on quantitative carcass characteristics}

The association of MSTN gene polymorphism with slaughtered weight in Indonesian Kampung and Broiler chicken showed in Table 2 . The c.234G>A generally had a significant effect on carcass components. There were significant associations between the MSTN polymorphism with live weight, carcass weight, breast weight, thigh weight, drumsticks weight, wings weight, breast muscle weight, thighs muscle weight, drumsticks muscle weight of 12 weeks-old Kampung chicken and wings weight on Broiler chicken. The genotype of AA and GA had higher on carcass component weight than the GG genotype.

\section{Discussion}

According to Zhang et al. (2012), a mutation in c. $234 \mathrm{G}>\mathrm{A}$ was reported to replace Guanine $(\mathrm{G})$ into adenine (A). The replaced was known as a transitional base substitution because it was still a kind of purine. According to Nei and Kumar (2000), substitutes for transitional bases were generally more common than transversions. This was a synonymous mutation that did not alter amino acid codes. The SNP replaced the AAG amino acid code into AAA, but the fixed amino acids remain Lysin.

Table 1. Frequency of genotype, allele, heterozygosity and Chi-square Mstn Exon 1

\begin{tabular}{|c|c|c|c|c|c|c|c|c|c|}
\hline \multirow{2}{*}{ Population } & \multirow{2}{*}{$\mathbf{n}$} & \multicolumn{3}{|c|}{ Genotype } & \multicolumn{2}{|c|}{ Allele } & \multirow{2}{*}{ He } & \multirow{2}{*}{ Ho } & \multirow{2}{*}{$\chi^{2}$} \\
\hline & & GG & GA & $\mathbf{A A}$ & $\mathbf{G}$ & $\mathbf{A}$ & & & \\
\hline Kampung & 67 & 0.03 & 0.46 & 0.51 & 0.26 & 0.74 & 0.39 & 0.46 & $\mathrm{~ns}$ \\
\hline Broiler chicken & 71 & 0.00 & 0.11 & 0.89 & 0.06 & 0.94 & 0.11 & 0.11 & ns \\
\hline Bian* & 118 & 0.38 & 0.43 & 0.19 & 0.60 & 0.40 & - & - & - \\
\hline Jinghai* & 50 & 0.04 & 0.42 & 0.54 & 0.25 & 0.75 & - & - & - \\
\hline Youxi* & 30 & 0.03 & 0.50 & 0.47 & 0.28 & 0.72 & - & - & - \\
\hline Arbor Acre* & 30 & 0.00 & 0.37 & 0.63 & 0.18 & 0.82 & - & - & - \\
\hline
\end{tabular}

Note: *Zhang et al. (2012); n: number of individuals; ns: not significant; He: Expected heterozigosity; Ho: Observed heterozigosity; $\chi 2$ : Chi-square 
Table 2. The association of the Mstn Exon 1 loci polymorphisms with carcass components in Kampung and Cobb Broiler Chicken

\begin{tabular}{|c|c|c|c|c|c|c|}
\hline \multirow{2}{*}{ Traits } & \multicolumn{3}{|c|}{ Kampung } & \multicolumn{3}{|c|}{ Broiler Chicken } \\
\hline & GG (2) & GA (13) & AA (15) & GG & GA(5) & $\mathbf{A A}(65)$ \\
\hline LW (g) & $705.00 \pm 120.21^{\mathrm{b}}$ & $930.00 \pm 93.63^{\mathrm{a}}$ & $924.67 \pm 96.94^{\mathrm{a}}$ & - & $2769.20 \pm 353.86$ & $2962.10 \pm 443.03$ \\
\hline CW (g) & $426.00 \pm 90.51^{\mathrm{b}}$ & $593.00 \pm 71.31^{\mathrm{a}}$ & $583.20 \pm 62.73^{\mathrm{a}}$ & - & $1909.00 \pm 257.37$ & $2022.77 \pm 273.42$ \\
\hline BW (g) & $115.50 \pm 26.10^{b}$ & $153.85 \pm 22.29^{\mathrm{a}}$ & $160.00 \pm 24.22^{\mathrm{a}}$ & - & $721.00 \pm 43.37$ & $755.83 \pm 110.35$ \\
\hline TW (g) & $84.50 \pm 26.16^{\mathrm{b}}$ & $104.08 \pm 13.55^{\mathrm{a}}$ & $103.27 \pm 13.46^{\mathrm{a}}$ & - & $326.40 \pm 44.84$ & $356.70 \pm 58.04$ \\
\hline DW (g) & $82.00 \pm 24.04^{b}$ & $101.85 \pm 15.05^{\mathrm{a}}$ & $95.27 \pm 10.49^{\mathrm{ab}}$ & - & $288.80 \pm 47.20$ & $318.33 \pm 53.50$ \\
\hline WW (g) & $70.00 \pm 25.46^{\mathrm{b}}$ & $86.54 \pm 11.23^{\mathrm{a}}$ & $82.80 \pm 7.79^{\mathrm{a}}$ & - & $210.80 \pm 32.90^{\mathrm{a}}$ & $233.27 \pm 28.50^{\mathrm{b}}$ \\
\hline BMW (g) & $69.50 \pm 16.26^{b}$ & $95.31 \pm 14.95^{\mathrm{a}}$ & $100.07 \pm 20.47^{\mathrm{a}}$ & - & $588.60 \pm 71.13$ & $588.30 \pm 97.19$ \\
\hline PMAW (g) & $50.50 \pm 12.02^{\mathrm{b}}$ & $67.38 \pm 10.82^{\mathrm{a}}$ & $71.87 \pm 15.31^{\mathrm{a}}$ & - & $454.00 \pm 52.48$ & $445.88 \pm 73.27$ \\
\hline PMIW(g) & $19.50 \pm 3.54^{\mathrm{b}}$ & $27.77 \pm 4.49^{\mathrm{a}}$ & $27.73 \pm 6.01^{\mathrm{a}}$ & - & $134.80 \pm 20.04$ & $142.28 \pm 24.45$ \\
\hline TMW (g) & $58.50 \pm 10.61^{\mathrm{b}}$ & $72.54 \pm 9.40^{\mathrm{a}}$ & $73.93 \pm 11.45^{\mathrm{a}}$ & - & $263.60 \pm 52.29$ & $277.40 \pm 44.28$ \\
\hline DMW (g) & $48.00 \pm 14.14^{\mathrm{b}}$ & $61.54 \pm 9.72^{\mathrm{a}}$ & $59.93 \pm 6.71^{\mathrm{a}}$ & - & $201.80 \pm 35.13$ & $218.80 \pm 38.82$ \\
\hline $\mathrm{CP}(\%)$ & $60.21 \pm 2.57$ & $63.76 \pm 16.58$ & $63.14 \pm 3.37$ & - & $69.05 \pm 4.60$ & $74.13 \pm 10.88$ \\
\hline $\mathrm{BP}(\%)$ & $16.30 \pm 0.93$ & $16.58 \pm 2.26$ & $17.29 \pm 1.74$ & - & $26.33 \pm 3.17$ & $27.73 \pm 4.71$ \\
\hline ТP (\%) & $11.91 \pm 0.88$ & $11.21 \pm 1.19$ & $11.19 \pm 1.07$ & - & $11.80 \pm 0.76$ & $13.02 \pm 1.79$ \\
\hline $\mathrm{DP}(\%)$ & $11.51 \pm 1.45$ & $10.98 \pm 1.49$ & $10.33 \pm 0.76$ & - & $10.42 \pm 0.82$ & $11.62 \pm 1.68$ \\
\hline WP (\%) & $9.76 \pm 1.95$ & $9.33 \pm 1.09$ & $8.99 \pm 0.67$ & - & $7.62 \pm 0.64$ & $8.58 \pm 1.40$ \\
\hline $\mathrm{BMP}(\%)$ & $9.80 \pm 0.64$ & $10.28 \pm 1.61$ & $10.78 \pm 1.65$ & - & $21.39 \pm 2.43$ & $21.58 \pm 4.08$ \\
\hline PMAP (\%) & $11.82 \pm 0.31$ & $11.36 \pm 1.27$ & $12.23 \pm 1.70$ & - & $23.90 \pm 1.21$ & $22.00 \pm 1.86$ \\
\hline PMIP (\%) & $16.97 \pm 0.78$ & $18.04 \pm 1.16$ & $17.26 \pm 2.38$ & - & $18.70 \pm 2.69$ & $18.80 \pm 1.69$ \\
\hline TMP (\%) & $8.29 \pm 0.09$ & $7.82 \pm 0.85$ & $8.00 \pm 0.93$ & - & $9.49 \pm 0.95$ & $10.15 \pm 1.57$ \\
\hline DMP (\%) & $6.74 \pm 0.86$ & $6.62 \pm 0.84$ & $6.50 \pm 0.58$ & - & $7.28 \pm 0.65$ & $7.99 \pm 1.28$ \\
\hline
\end{tabular}

Note: LW: Live Weight; CW: Carcass Weight; BW: Breast Weight; TW: Thighs Weight; DW: Drum Sticks Weight; WW: Wings Weight; BMW: Breast Muscle Weight; PMAW: Pectoralis Mayor Weight; PMIW: Pectoralis Minor Weight; TMW: Thighs Muscle Weight; DMW: Drum Sticks Muscle Weight; CP: Carcass Percentage; BP: Breast Percentage; TP: Thighs Percentage; DP: Drum Sticks Percentage; WP: Wings Percentage; BMP: Breast Muscle Percentage; PMAP: Pectoralis Mayor Percentage; PMIP: Pectoralis Minor Percentage; TMP: Thighs Muscle Percentage; DMP: Drum Sticks Muscle Percentage; n: number of a sample; different superscript indicates a significant difference at the $\mathrm{P}<0.05$ levels for chickens with different genotypes of a given locus

The entire population analyzed shows that the c.234G> A mutation point is polymorphic, and this is because a genotype polymorphism was found in 6 chicken populations. This is in accordance with Allendorf et al. (2013), a population is classified as polymorphic if it has an allele frequency of less than 0.99. Several studies on the polymorphism of MSTN genes have been carried out. Zhang et al. (2012a) state that the mutation points of G673A and G985A are monomorphic in the bian and arbor acre chicken populations but polymorphic in jinghai and youxi chickens, whereas at the mutation point A1278T is polymorphic in 4 populations. The T4842G mutation point is polymorphic in 6 Indonesian chicken populations (Khaerunnisa et al. 2016). The mutation points of C334G, C1346T, G1375A, A1473G, G1491A on 5'UTR are polymorphic (Zhang et al. 2012b). Noor (2010) states that gene frequency can experience changes if there is selection, mutation, population mixing, inner crossing, and external crossing and genetic drift.

The results observed showed that the population of native chickens and Broilers did not have high exon 1 MSTN polymorphism. He value in the native chicken population is only 0.386 and in Broilers 0.106. Allendorf et al. (2013) stated that the genetic polymorphism of a population is stated to be high if the heterozygosity value is more than 0.5 .

He values in Broiler chicken is lower if compared with He value in Kampung chicken. The low value of heterozygosity in Broilers can be due to intensive selection of Broiler chickens, especially the MSTN gene, which plays a role in influencing carcass and meat quality, while high heterozygosity values in native chickens are due to the absence of intensive selection and random mating because maintenance is not intensive. heterozygosity was used to determine the polymorphism of genes in a population that can help in the selection program for the next generation.

Zhang et al. (2012) added that alleged substitution at point c. $234 \mathrm{G}>$ A could affect the efficiency of transcription and function as a negative regulator by suppressing MSTN expression in bian chicken. The MSTN gene functions as a negative regulator of muscle growth and plays an important role in skeletal muscle homeostasis (Burks and Cohn 2011). According to Lee et al. (2016), MSTN is paracrine and autocrine whose mutations can cause gene expression to change and result in an increase in muscle mass. Individuals will experience 2 to 3 times greater muscle development if they have a mutation in the MSTN gene caused by hyperplasia and hypertrophy in livestock (Lee et al. 2016; Grade et al. 2019). Deficient of MSTN display an increase in skeletal muscle mass known as double muscling (DBM) (Aiello et al, 2018). According to Fiems (2012), this naturally occurring mutation results in inactivation of the MSTN gene and provokes a massive increase in the skeletal muscle mass.

In conclusion, the results suggested the MSTN gene in Kampung chicken and Broiler chicken populations is polymorphic. The frequency of the AA genotype is higher than that of the GA and GG genotypes. In Broilers, GG 
genotype was found. The frequency of allele $\mathrm{A}$ is higher compared to allele $\mathrm{G}$ in all populations. The genotype of $\mathrm{AA}$ and GA had higher on carcass component weight than the GG genotype. It was concluded that the c. $234 \mathrm{G}>\mathrm{A}$ mutation in exon 1 could be potentially recommended as a genetic marker for chicken slaughtered weight traits.

\section{REFERENCES}

Aiello D, Patel K, Lasagna E. 2018. The myostatin gene: an overview of mechanisms of action and its relevance to livestock animals. Anim Genet 49: 505-519.

Allendorf FW, Luikart G, Aitken SN. 2013. Conservation and The Genetics of Populations. Blackwell Publishing, Oxford, UK

Beyer TA, Narimatsu M, Weiss A, David L, Wrana JL. 2013. The TGFb superfamily in stem cell biology and early mammalian embryonic development. Biochimica et Biophysica Acta 1830: 2268-2279.

Boman IA, Klemetsdal G, Nafstad O, Blichfeldt T, Vage DI. 2010. Impact of two myostatin (MSTN) mutations on weight gain and lamb carcass classification in Norwegian White Sheep (Ovis aries). Genet Select Evol 42 (4): 1-7.

Breitbart A, Auger-Messier M, Molkentin JD, Heineke J. 2011. Myostatin from the heart: local and systemic actions in cardiac failure and muscle wasting. Am J Physiol Heart Circ Physiol 300: 1973-1982.

Burks TN, Cohn RD. 2011. Role of TGF- $\beta$ Signaling in inherited and acquired myopathies. Skelet Muscle 1: 19.

Fiems LO. 2012. Double muscling in cattle: genes, husbandry, carcasses and meat. Animals 2: 472-506.

Genxi Z, Guojun D, Jinyu W, Yue W, Fuxiang D, Zhang L, Xiuhua Z, Khaizou X, Wenhou W. 2014. Polymorphisms in 5'upstream region of the myostatin gene in four chicken breeds and its relationship with growth traits in the Bian chicken. Afr J Biotech 11: 9677-9682.

Grade CVC, Mantovani CS, Alvares LE. 2019. Myostatin gene promoter: structure, conservation and importance as a target for muscle modulation. J Anim Sci Biotechnol 10: 32.

Khaerunnisa I, Pramujo M, Irma IA, Budiman C, Gunawan A, Jakaria, Sumantri C. 2016. Polymorphism of the T4842G Myostatin gene is associated with carcass characteristics in Indonesia chicken. Intl J Poult Sci 15 (8): 316-324.

Lee SJ. 2010. Extracellular regulation of myostatin: a molecular rheostat for muscle mass. Immunol Endocr Metab Agents Med Chem 10: 183194.

Lee YS, Huynh TV, Lee SJ. 2016. Paracrine and endocrine modes of myostatin action. J Appl Physiol 120: 592-598.

Naji TAA, Amadou I, Zhao RY, Tang X, Shi YH, Le GW. 2014. Effects of phytosterol in feed on growth and related gene expression in muscles of Broiler chicken. Trop J Pharm Res 13 (1): 9-16.

Nei M, Kumar S. 2000. Molecular Evolution and Phylogenetics. Oxford University Press, New York.

Noor RR. 2010. Genetika Ternak. Penebar Swadaya, Jakarta. [Indonesian]

Sambrook J, Russell D. 2001. Molecular Cloning: A Laboratory Manual $3^{\text {rd }}$ ed. Cold Spring Harbor Laboratory Press, USA

Stinckens A, Georges M, Buys N. 2010. Mutations in the Myostatin gene leading to hypermuscularity in mammals: indications for a similar mechanism in fish? Anim Genet 42: 229-234.

Zhang G, Dai G, Wang J, Wei Y, Ding F, Zhang L, Zhao X, Xie K, Wang W. 2012a. polymorphisms in 5'-upstream region of the myostatin gene in four chicken breeds and its relationship with growth traits in the bian chicken. Afr J Biotech 11 (40): 9677-9682.

Zhang G, Zhang L, Wei Y, Wang J, Ding F, Dai G, Xie K. 2012b. Polymorphisms of the myostatin gene and its relationship with reproduction traits in the bian chicken. Anim Biotech 23: 184-193.

Zhang G, Zhao XH, Wang JY, Ding FX, Zhang L. 2012. Effect of an exon 1 mutation in the myostatin gene on the growth traits of the Bian chicken. Anim Genet 43: 458-459. 